\title{
University College London
}

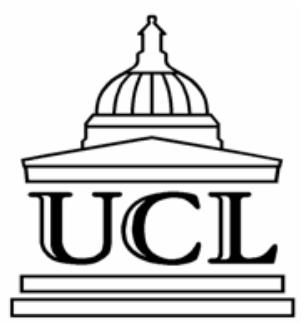

\section{DISCUSSION PAPERS IN ECONOMICS}

\section{MULTINATIONAL OWNERSHIP AND SUBSIDIARY INVESTMENT}

$$
\text { by }
$$

Wendy Carlin, Andrew Charlton and Colin Mayer

Discussion Paper 06-03

DEPARTMENT OF ECONOMICS

UNIVERSITY COLLEGE LONDON

GOWER STREET

LONDON WCIE 6BT 


\title{
Multinational Ownership and Subsidiary Investment
}

\author{
Wendy Carlin \\ UCL and CEPR \\ Andrew Charlton \\ Centre for Economic Performance, LSE \\ Colin Mayer \\ Saïd Business School, University of Oxford and CEPR
}

January 2007

\begin{abstract}
This paper examines how foreign ownership affects the investment decisions of subsidiary firms. In particular, our data allow us to analyse how the investment decisions of multinational subsidiaries respond to the financial circumstances of their parent firms. We find that improvements in the investment opportunities of parent firms have a negative effect on the investment of their subsidiaries, after controlling for the investment opportunities of the subsidiary. This provides evidence of internal capital markets in multinationals that reallocate funds towards units with better investment opportunities. We further explore how financial relationships within multinational firms are affected by the proximity of the parent and subsidiary and by the level of financial development in the subsidiary's host country. We find that the negative effect of the parent's investment opportunities on subsidiary investment is greatest where parents have modest ownership stakes and are distant from their subsidiaries and when subsidiaries operate in well developed financial markets.
\end{abstract}

\section{Key words: Investment, Internal Capital Markets, Foreign Ownership} JEL Classification: F21, G31

We are grateful for comments and suggestions made on an earlier version of this paper by Nick Bloom, Richard Blundell, Michael Devereux, Andrew Glyn, Tomasz Mickiewiecz, Imran Rasul and Jeremy Stein and in seminars or conferences at CEDI (Brunel), CEP (LSE), CERGE-EI, Prague, the EBRD, RIETI, Tokyo and the WZB, Berlin. 
The pace of global financial integration has raised questions about the impact of foreign ownership on host country economies. Some see multinationals as bringing much needed capital and financial stability to underdeveloped economies, while others emphasize the volatility produced by footloose foreign investors. ${ }^{1}$ Underlying these issues are fundamental questions related to the investment behavior of related firms within multinational networks.

In this paper we investigate one aspect of the operation of internal capital markets within multinational firms. We examine how investment in subsidiaries is affected by the financial circumstances of parent firms. We create a new panel dataset of almost 5,000 parents and subsidiaries for which we can separately observe necessary financial and operating information because they are independently listed on different national exchanges. We find that increased investment opportunities in the parent firm have a negative effect on the investment of the subsidiary after controlling for the subsidiaries' investment opportunities. We further analyze how financial decisions are affected by the characteristics of the parentsubsidiary relationship. We find that reallocation is strongest when parents are distant from their subsidiaries and have modest ownership stakes and when subsidiaries operate in well developed financial markets. This suggests that internal competition is strongest where the scope for "influence activities" is weakest.

The investment behaviour of firms inside multinational networks relates to two distinct debates in the literature - on the existence and effects of internal capital markets and on the impact of foreign ownership on parent and host economies. The existing literature on intrafirm financial relationships suggests ambiguous predictions of the effect of an increase in the multinational parent's investment opportunities on the investment of the subsidiary. On the one hand, parents may impose discipline on subsidiaries by reallocating funds from those with greater access to those with greater need of resources (Stein (2003)). In the presence of capital market imperfections, subsidiaries benefit from the access to

\footnotetext{
${ }^{1}$ For example, Radelet and Sachs (1998).
} 
external markets that parents provide (Inderst and Muller (2003)) or are able to access finance from other units within the multinational network (Stein, 2003). On the other hand, headquarters may support their poorly performing entities. Brusco and Panunzi (2005) claim that redistribution of capital between divisions weakens managerial incentives and Milgrom (1988), Milgrom and Roberts (1988) and Meyer, Milgrom and Roberts (1992) point to the wasteful influence activities - rent-seeking and power struggles - in which managers of large organizations engage. ${ }^{2}$ This leads to soft budget constraints that cause internal capital markets to allocate too many resources to low value divisions and too few to high value divisions (Lamont 1997, Rajan, Servaes and Zingales, 2000, Scharfstein, 1998, Scharfstein and Stein, 2000, Shin and Stulz, 1998).

The first contribution of the paper is to extend this literature to the context of separate firms within multinational networks. We analyze investment in a sample of subsidiary firms in more than 60 countries, which are more than 50 per cent owned by a parent firm, and which are also separately listed on stock markets. We choose listed multinational firms to overcome the primary identification problem in the literature on diversified firms: inadequate proxies for the investment opportunities of individual divisions of conglomerates. Since both our parents and subsidiaries are quoted we can separately observe their investment opportunities as proxied by their separate Tobin's $Q$. We find that increases in the parents' investment opportunities (proxied by their $Q$ ) are associated with reductions in the subsidiaries' investment, after controlling for the subsidiaries' $Q$. We interpret this as evidence that multinational parents reallocate funds towards units with better investment opportunities.

These results also bear on the debate on the impact of foreign capital on host economies. ${ }^{3}$ Understanding how internal capital markets operate in multinational firms is relevant to the question of whether foreign owners support their subsidiaries through down-turns as suggested by the 'bail out' hypothesis or whether they are the first to withdraw their investment in the face of negative shocks

\footnotetext{
${ }^{2}$ Diversified conglomerates generally trade at lower value than comparable portfolios of specialized firms (Bhagat, Shleifer and Vishny (1990), Berger and Ofek (1996)).

${ }^{3}$ On the one hand, foreign direct investment may bring various technology and productivity advantages that spill over to domestic firms and it may be more stable than other forms of foreign capital. On the other hand, FDI may crowd out domestic firms and may be more volatile than domestic investment.
} 
(Lipsey 2001). To motivate our investigation with an example, consider the Asian crisis of 1997-98 - an event that generated considerable interest in the potential macroeconomic impact of the presence of foreign-owned firms on host economies. We find in our data that during the crisis foreign owned firms decreased their investment by $20 \%$ more than domestically owned firms (Table I). Moreover, amongst the foreign-owned firms, investment was cut back by more in subsidiaries with parents located outside the region than by those with parents in Asia. As shown in Table I, the investment opportunities (measured by their Tobin's $Q$ ) of the parent firms with headquarters outside the region rose whilst they fell for the Asian-based parents. This pattern - of a negative correlation between the change in parent's investment opportunities and the change in the investment of their subsidiaries - is consistent with multinational firms reallocating capital to the most profitable investment opportunities within their international network.

Table I: Change in Investment in East Asian firms in 1996-1998

This table reports summary statistics for listed firms operating in Hong Kong, Indonesia, Korea, Malaysia, the Philippines, Singapore and Thailand, which reported their capital expenditure as a proportion of total assets. The table shows the average change in investment on total assets over the period 1996-1998. Parent's Q is the Tobin's $\mathrm{Q}$ of the parent firms divided into those parents located in the same region and those located outside the region. For each row $* * *, * *, *$ indicates the significance of difference with previous column at $1 \% ; 5 \%$ and $10 \%$ level.

Change in investment/total assets (Inv./TA) Change in Inv./TA (\%)

Change in parent's Q

Change in subsidiary's Inv./TA by foreign-owned

\begin{tabular}{cc} 
firms & by domestic firms \\
\hline-0.031 & $-0.022 * *$ \\
$-68 \%$ & $-48 \%$
\end{tabular}

where parent is

in

\begin{tabular}{cc} 
Asia & outside Asia \\
\hline-0.35 & $0.12 * * *$ \\
-0.021 & $-0.035 *$
\end{tabular}

Our second contribution is to examine how the parent-subsidiary financing relationship is affected by their proximity and characteristics of the host country. Proximity has an a priori ambiguous effect on the extent of reallocation within the multinational network. On the one hand, more proximate owners may have more control over their subsidiaries and thus be in a stronger position to reallocate. On the other hand, proximity may increase the potential for influence activities on the part of the managers of under performing units. To examine these effects we consider various concepts of proximity. We use 
geographical distance between the two (physical proximity), differences in the level of financial development between the parent and subsidiary countries (institutional proximity), and the size of the parent's stake in the subsidiary (concentration of ownership) as proxies for the proximity of the parentsubsidiary relationship.

There is no consensus in the existing theoretical or empirical literature as to whether greater proximity along these dimensions is likely to enhance or reduce the responsiveness of subsidiary investment to the parent's investment opportunities. Concentrated owners may be able to exercise stronger governance (Allen and Gale, 2000) than dispersed owners but may intervene excessively and undermine the autonomy of local management (Burkhart, Gromb and Panunzi, 1997). Financial relationships and the quality of information about subsidiaries may weaken with distance between parents and subsidiaries (Portes and Rey, 2001 and Wei and Wu, 2002) ${ }^{4}$ but so too may influence costs. Foreign affiliates may be able to substitute internal for external borrowing when operating in poorly developed financial markets (Desai, Foley and Hines, 2004) but may also be particularly prone to adverse influence costs. ${ }^{5}$ We find that reallocation is strongest when parents are distant from their subsidiaries and have modest ownership stakes and when subsidiaries operate in well developed financial markets. This suggests that internal competition is strongest where the scope for influence activities is weakest.

The paper is organized as follows. Section I explains how the dataset was created and Section II reports our results on parent investment opportunities and subsidiary investment. In Section III we investigate whether more distant parents are less strict on their subsidiaries and in Section IV whether parents reallocate more when subsidiaries are located in weaker financial markets. Section V summarizes our findings.

\footnotetext{
${ }^{4}$ Grinblatt and Keloharju (2001) find that investors are more likely to trade the stocks of firms that are proximate, communicate in the investor's native tongue, and have similar cultural attributes. Guiso, Sapienza and Zingales (2004) find that even in a country with uniform regulatory and institutional structures (Italy) access to finance for small firms depends on local financial development: distance matters. Buch (2005) finds that banks hold significantly lower assets in distant markets. In a study of loans in Pakistan, Mian (2005) finds that foreign banks do not lend to 'informationally difficult' yet fundamentally sound firms. Lending declines as geographical and cultural distance between the bank's headquarters and its local branches rises.

${ }^{5}$ See, for example, the discussion of the behaviour of MNEs in India toward their listed subsidiaries in 2000 ('Why Bombay's Blue Chips are down: Local investors suspect multinationals give them a raw deal' Business Week Online October $30^{\text {th }} 2000$ ).
} 


\section{Investment by listed multinationals}

Our sample is obtained from the OSIRIS database provided by Bureau van Dijk Electronic Publishing, which gathers its information from several sources including World'Vest Base, Fitch, Thomson Financial, Reuters, and Moody's. This database is a "comprehensive database of listed companies ... around the world" and provides information on 28,915 firms listed on the world's stock exchanges. Table II presents the distribution of these firms by country. The 69 countries in the data base include 23 'old' OECD countries including Japan (19,576 firms), ten former Soviet bloc transition countries (281 firms), eleven Asian countries (6,456 firms), 467 firms from African countries, 910 from the Middle East and 1,225 from Central and Latin America.

\section{Ownership data}

The OSIRIS data base records a firm as having a parent if another entity has financial and legal responsibility for it, i.e. it holds more than 50 per cent and less than 100 per cent of the subsidiary's equity. This is a strong definition of ownership, which enables us to observe situations in which the parent firm has enough authority to control the financial decisions of its subsidiaries and operate an internal capital market. Table II indicates the distribution of listed firms in each country across ownership categories (subsidiary, parent, and the remaining stand alone firms).

We discard firms from the sample if they experienced a change in ownership over the period, or if their ownership information is unavailable, or if key financial information (matched to and collected from Datastream) is missing over the period 1994 to 2005. OSIRIS only reports ownership at one point in time, 2005, but we have older ownership data from Dun and Bradstreet, which enables us to identify ownership in 1994. After matching these data we exclude firms from the sample if the location of their owner is different in these two datasets. Because we have no information on when ownership changed, we cannot make use of the subsample of firms for which ownership changes. This leaves us with 4,886 subsidiaries which have been continuously owned and controlled by 1,028 distinct global ultimate firms over the period. By excluding subsidiaries that were spun off or acquired between 1994 and 2005 we 
Table II: Firm Ownership Data: Summary Statistics by Country

This table provides summary statistics for our sample across countries. Firms refers to the number of listed firms in each country. Subsidiaries are the number of these that report parents, i.e. they report that they are more than $50 \%$ and less than $100 \%$ owned by another entity. Parent's of subsidiaries are firms which own more than 50\% of another listed firm in their own country or around the world. Stand-alone firms have neither a parent nor subsidiary relationship. Foreign owned subsidiaries are firms which own another listed firm in another country. Parent of foreign subsidiaries are firms which own a listed subsidiary in another country.

\begin{tabular}{|c|c|c|c|c|c|c|}
\hline Country & $\begin{array}{c}\text { Number } \\
\text { (1) }\end{array}$ & $\begin{array}{c}\text { (\% firms) } \\
(2)\end{array}$ & $\begin{array}{l}\text { Parent of } \\
\text { subsidiaries } \\
\text { (\% firms) } \\
(3)\end{array}$ & $\begin{array}{l}\begin{array}{c}\text { Stand- } \\
\text { alone }\end{array} \\
\text { (\% firms) } \\
\text { (4) }\end{array}$ & $\begin{array}{l}\text { Foreign- } \\
\text { owned } \\
\text { subsidiaries } \\
\text { (\% firms) } \\
(5)\end{array}$ & $\begin{array}{l}\text { Parent of } \\
\text { foreign } \\
\text { subsidiaries } \\
\text { (\% firms) } \\
\text { (6) }\end{array}$ \\
\hline Argentina & 92 & $45 \%$ & $1 \%$ & $54 \%$ & $20 \%$ & $1 \%$ \\
\hline Australia & 1362 & $16 \%$ & $3 \%$ & $81 \%$ & $13 \%$ & $3 \%$ \\
\hline Austria & 90 & $31 \%$ & $3 \%$ & $66 \%$ & $7 \%$ & $3 \%$ \\
\hline Bahrain & 28 & $32 \%$ & $4 \%$ & $64 \%$ & $21 \%$ & $4 \%$ \\
\hline Belgium & 137 & $42 \%$ & $4 \%$ & $54 \%$ & $13 \%$ & $4 \%$ \\
\hline Brazil & 401 & $36 \%$ & $1 \%$ & $63 \%$ & $14 \%$ & $1 \%$ \\
\hline Canada & 1356 & $22 \%$ & $3 \%$ & $76 \%$ & $15 \%$ & $2 \%$ \\
\hline Chile & 232 & $26 \%$ & $2 \%$ & $72 \%$ & $12 \%$ & $2 \%$ \\
\hline China & 1316 & $15 \%$ & $0 \%$ & $85 \%$ & $14 \%$ & $0 \%$ \\
\hline Colombia & 77 & $22 \%$ & $3 \%$ & $75 \%$ & $12 \%$ & $3 \%$ \\
\hline Costa Rica & 17 & $12 \%$ & $0 \%$ & $88 \%$ & $6 \%$ & $0 \%$ \\
\hline Croatia & 23 & $48 \%$ & $0 \%$ & $52 \%$ & $17 \%$ & $0 \%$ \\
\hline Czech Republic & 49 & $45 \%$ & $0 \%$ & $55 \%$ & $14 \%$ & $0 \%$ \\
\hline Denmark & 147 & $26 \%$ & $3 \%$ & $71 \%$ & $10 \%$ & $3 \%$ \\
\hline Egypt & 364 & $14 \%$ & $0 \%$ & $86 \%$ & $11 \%$ & $0 \%$ \\
\hline Estonia & 13 & $54 \%$ & $0 \%$ & $46 \%$ & $15 \%$ & $0 \%$ \\
\hline Finland & 127 & $28 \%$ & $5 \%$ & $68 \%$ & $8 \%$ & $5 \%$ \\
\hline France & 699 & $56 \%$ & $6 \%$ & $38 \%$ & $9 \%$ & $6 \%$ \\
\hline Germany & 756 & $47 \%$ & $4 \%$ & $48 \%$ & $13 \%$ & $4 \%$ \\
\hline Greece & 233 & $58 \%$ & $3 \%$ & $39 \%$ & $11 \%$ & $3 \%$ \\
\hline Hong Kong & 269 & $19 \%$ & $3 \%$ & $78 \%$ & $7 \%$ & $3 \%$ \\
\hline Hungary & 28 & $18 \%$ & $7 \%$ & $75 \%$ & $7 \%$ & $7 \%$ \\
\hline Iceland & 14 & $21 \%$ & $7 \%$ & $71 \%$ & $7 \%$ & $7 \%$ \\
\hline India & 736 & $21 \%$ & $1 \%$ & $78 \%$ & $9 \%$ & $1 \%$ \\
\hline Indonesia & 297 & $19 \%$ & $0 \%$ & $81 \%$ & $13 \%$ & $0 \%$ \\
\hline Ireland & 64 & $25 \%$ & $9 \%$ & $66 \%$ & $11 \%$ & $9 \%$ \\
\hline Israel & 169 & $17 \%$ & $1 \%$ & $82 \%$ & $8 \%$ & $1 \%$ \\
\hline Italy & 229 & $53 \%$ & $6 \%$ & $41 \%$ & $11 \%$ & $6 \%$ \\
\hline Jamaica & 30 & $43 \%$ & $3 \%$ & $53 \%$ & $3 \%$ & $3 \%$ \\
\hline Japan & 3598 & $14 \%$ & $2 \%$ & $83 \%$ & $8 \%$ & $2 \%$ \\
\hline Jordan & 31 & $16 \%$ & $0 \%$ & $84 \%$ & $6 \%$ & $0 \%$ \\
\hline Kazakhstan & 15 & $27 \%$ & $0 \%$ & $73 \%$ & $13 \%$ & $0 \%$ \\
\hline Kenya & 13 & $38 \%$ & $0 \%$ & $62 \%$ & $0 \%$ & $0 \%$ \\
\hline Korea, Rep. of & 1460 & $39 \%$ & $1 \%$ & $60 \%$ & $8 \%$ & $1 \%$ \\
\hline $\begin{array}{l}\text { Kuwait } \\
\text { continued.... }\end{array}$ & 49 & $10 \%$ & $2 \%$ & $88 \%$ & $4 \%$ & $2 \%$ \\
\hline
\end{tabular}


Table II: Firm Ownership Data: Summary Statistics by Country (Continued)

\begin{tabular}{|c|c|c|c|c|c|c|}
\hline Country & $\begin{array}{c}\text { Number } \\
\text { (1) }\end{array}$ & $\begin{array}{l}\text { Subsidiaries } \\
\text { (\% firms) } \\
(2)\end{array}$ & $\begin{array}{l}\text { Parent of } \\
\text { subsidiaries } \\
\text { (\% firms) } \\
(3)\end{array}$ & $\begin{array}{l}\begin{array}{c}\text { Stand- } \\
\text { alone }\end{array} \\
\text { (\% firms) } \\
\text { (4) }\end{array}$ & $\begin{array}{c}\text { Foreign- } \\
\text { owned } \\
\text { subsidiaries } \\
\text { (\% firms) } \\
(5)\end{array}$ & $\begin{array}{l}\text { Parent of } \\
\text { foreign } \\
\text { subsidiaries } \\
\text { (\% firms) } \\
\quad(6)\end{array}$ \\
\hline Latvia & 23 & $35 \%$ & $0 \%$ & $65 \%$ & $9 \%$ & $0 \%$ \\
\hline Lithuania & 10 & $60 \%$ & $0 \%$ & $40 \%$ & $20 \%$ & $0 \%$ \\
\hline Luxembourg & 37 & $41 \%$ & $5 \%$ & $57 \%$ & $14 \%$ & $5 \%$ \\
\hline Malaysia & 941 & $13 \%$ & $1 \%$ & $86 \%$ & $7 \%$ & $1 \%$ \\
\hline Mauritius & 37 & $11 \%$ & $0 \%$ & $89 \%$ & $8 \%$ & $0 \%$ \\
\hline Mexico & 141 & $26 \%$ & $8 \%$ & $66 \%$ & $4 \%$ & $8 \%$ \\
\hline Morocco & 13 & $46 \%$ & $0 \%$ & $54 \%$ & $8 \%$ & $0 \%$ \\
\hline Netherlands & 175 & $22 \%$ & $14 \%$ & $65 \%$ & $6 \%$ & $14 \%$ \\
\hline New Zealand & 110 & $18 \%$ & $1 \%$ & $81 \%$ & $8 \%$ & $1 \%$ \\
\hline Nigeria & 32 & $16 \%$ & $0 \%$ & $84 \%$ & $9 \%$ & $0 \%$ \\
\hline Norway & 136 & $27 \%$ & $5 \%$ & $68 \%$ & $6 \%$ & $5 \%$ \\
\hline Pakistan & 140 & $21 \%$ & $2 \%$ & $76 \%$ & $2 \%$ & $2 \%$ \\
\hline Panama & 15 & $20 \%$ & $0 \%$ & $80 \%$ & $13 \%$ & $0 \%$ \\
\hline Peru & 162 & $26 \%$ & $0 \%$ & $74 \%$ & $6 \%$ & $0 \%$ \\
\hline Philippines & 226 & $16 \%$ & $1 \%$ & $83 \%$ & $8 \%$ & $1 \%$ \\
\hline Poland & 64 & $59 \%$ & $0 \%$ & $41 \%$ & $13 \%$ & $0 \%$ \\
\hline Portugal & 72 & $44 \%$ & $7 \%$ & $50 \%$ & $10 \%$ & $7 \%$ \\
\hline Russia & 45 & $42 \%$ & $0 \%$ & $58 \%$ & $7 \%$ & $0 \%$ \\
\hline Saudi Arabia & 16 & $31 \%$ & $0 \%$ & $69 \%$ & $13 \%$ & $0 \%$ \\
\hline Singapore & 516 & $19 \%$ & $2 \%$ & $79 \%$ & $8 \%$ & $2 \%$ \\
\hline Slovakia & 11 & $45 \%$ & $0 \%$ & $55 \%$ & $0 \%$ & $0 \%$ \\
\hline South Africa & 319 & $20 \%$ & $6 \%$ & $73 \%$ & $1 \%$ & $6 \%$ \\
\hline Spain & 148 & $45 \%$ & $8 \%$ & $48 \%$ & $11 \%$ & $8 \%$ \\
\hline Sri Lanka & 135 & $10 \%$ & $3 \%$ & $87 \%$ & $4 \%$ & $3 \%$ \\
\hline Sweden & 242 & $35 \%$ & $9 \%$ & $57 \%$ & $3 \%$ & $9 \%$ \\
\hline Switzerland & 224 & $48 \%$ & $8 \%$ & $44 \%$ & $12 \%$ & $8 \%$ \\
\hline Thailand & 420 & $13 \%$ & $1 \%$ & $86 \%$ & $6 \%$ & $1 \%$ \\
\hline Tunisia & 40 & $28 \%$ & $3 \%$ & $70 \%$ & $5 \%$ & $3 \%$ \\
\hline Turkey & 242 & $14 \%$ & $1 \%$ & $84 \%$ & $4 \%$ & $1 \%$ \\
\hline United Arab E. & 11 & $36 \%$ & $0 \%$ & $64 \%$ & $9 \%$ & $0 \%$ \\
\hline United Kingdom & 1869 & $20 \%$ & $10 \%$ & $71 \%$ & $9 \%$ & $9 \%$ \\
\hline United States & 7751 & $20 \%$ & $4 \%$ & $76 \%$ & $3 \%$ & $4 \%$ \\
\hline Venezuela & 58 & $19 \%$ & $0 \%$ & $81 \%$ & $3 \%$ & $0 \%$ \\
\hline Zimbabwe & 13 & $31 \%$ & $8 \%$ & $62 \%$ & $0 \%$ & $8 \%$ \\
\hline
\end{tabular}


minimize the selection problem, discussed further in Section II, which characterizes the use of spin-offs to test for the operation of an internal capital market.

Table III presents basic descriptive data for the sample firms. Foreign owners are the largest firms, with median employees of 74,598, foreign-owned firms have 7,252, and stand-alone domestic firms have an average number of 8,023 . The size of the shareholding of the largest foreign owner is around $60 \%$ in the owned firms and less than $10 \%$ in the stand-alone firms. In addition to the size of ownership, we also observe the country in which parent firms are located. The average distance of foreign-owned firms from their parents is $40 \%$ of half the circumference of the world. The foreign-owned firms operate in economies in which stock markets are significantly smaller and which have lower financial development than is the case for stand-alone or owner firms in the sample (see Table III).

\section{Financial and investment data}

The OSIRIS data-base reports a unique identification number for each parent firm that enables us to match firms with financial data on their parents. This was merged with the market and financial data from Datastream. We have time series observations on firms over the period from 1994 to 2005 . The average number of observations per firm is six.

Capital expenditure measures funds used to acquire fixed assets including expenditures on plant and equipment, structures and property but excluding any expenditures associated with mergers or acquisitions. To account for differences in size and for inflation over time and to avoid heteroscedasticity we divide investment by total assets at the beginning of the period.

We use a measure of Tobin's $Q$ as a proxy for the assessment by the market of the investment opportunities available to the parent firm. Theoretically, marginal $Q$ should be used as the approximation of present and expected future investment opportunities but since marginal $Q$ is unobservable, we use average $Q$ as a proxy. We measure average $Q$ as the firm's market-to-book ratio at the end of the prior fiscal year. The parent's data is given in consolidated form, so we take out the effect of the subsidiary to 
extract the parent's $Q$ - in essence we are measuring the $Q$ of all the other units in the consolidated firm except the subsidiary. ${ }^{6}$

Table III. Descriptive characteristics of sample firms

These data are for the firms for which we have ownership and location and financial data (i.e. the regression sample). Investment on total assets is Datastream item 08416 Asset Utilization Ratio measured as the annual item Capital Expenditures / (Total Assets - Customer Liabilities on Acceptances). Cash-flow is Datastream item 04860 (Net cash flow from operating activities) divided by total assets. Q is the share price divided by the book value per share (Datastream PTBV). Sales growth is the log difference in sales in US\$ from Datastream item number 07240. Distance to owner is the great circle distance between capital cities of the two countries measured as a percentage of half the earth's circumference (i.e. max is 100). Employees is Datastream item WC07011.

\begin{tabular}{|c|c|c|c|c|c|c|}
\hline & & Subsidiaries & $\begin{array}{l}\text { Parent } \\
\text { of subs. }\end{array}$ & $\begin{array}{l}\text { Stand- } \\
\text { alone }\end{array}$ & $\begin{array}{c}\text { Foreign- } \\
\text { owned } \\
\text { subs. }\end{array}$ & $\begin{array}{l}\text { Parent of } \\
\text { foreign } \\
\text { subs. }\end{array}$ \\
\hline \multicolumn{2}{|l|}{ Firms } & 4,886 & 1,028 & 16,272 & 2,833 & 969 \\
\hline \multicolumn{2}{|l|}{ Date of Incorporation } & 1969 & 1963 & 1974 & 1968 & 1961 \\
\hline \multicolumn{2}{|l|}{ Employees } & 6,643 & 63,208 & 8,023 & 7,252 & 74,598 \\
\hline \multirow[t]{3}{*}{ Investment/Assets } & Mean & 0.051 & 0.051 & 0.045 & 0.05 & 0.051 \\
\hline & Std dev. & 0.052 & 0.045 & 0.051 & 0.053 & 0.044 \\
\hline & Median & 0.036 & 0.042 & 0.032 & 0.035 & 0.042 \\
\hline \multirow[t]{3}{*}{ Cash Flow / Assets } & Mean & 0.07 & 0.075 & 0.063 & 0.066 & 0.075 \\
\hline & Std dev. & 0.074 & 0.062 & 0.076 & 0.073 & 0.06 \\
\hline & Median & 0.069 & 0.074 & 0.061 & 0.065 & 0.074 \\
\hline \multirow[t]{3}{*}{ Sales growth } & Mean & 0.068 & 0.092 & 0.07 & 0.069 & 0.094 \\
\hline & Std dev. & 0.244 & 0.233 & 0.25 & 0.252 & 0.233 \\
\hline & Median & 0.069 & 0.085 & 0.071 & 0.074 & 0.086 \\
\hline \multirow[t]{3}{*}{$Q$} & Mean & 1.6 & 1.96 & 1.58 & 1.59 & 1.96 \\
\hline & Std dev. & 1.06 & 1.05 & 1.06 & 1.08 & 1.05 \\
\hline & Median & 1.33 & 1.74 & 1.32 & 1.31 & 1.74 \\
\hline \multicolumn{2}{|c|}{ Shareholding of Largest Owner } & 61.91 & & 9.02 & 57.45 & \\
\hline \multirow[t]{3}{*}{ Dist. to owner/( $\pi . r) \%$} & Mean & 35.8 & 34.5 & & 38.3 & 35 \\
\hline & Std dev. & 23.7 & 25.1 & & 22.4 & 24.9 \\
\hline & Median & 36.1 & 32 & & 40.4 & 32 \\
\hline \multirow[t]{3}{*}{ Stock Market/GDP \% } & Mean & 49.6 & 58.6 & 60.3 & 53.2 & 58.1 \\
\hline & Std dev. & 30.9 & 27.7 & 32 & 34 & 28 \\
\hline & Median & 53.2 & 53.2 & 53.2 & 53.2 & 53.2 \\
\hline \multirow[t]{3}{*}{ Private Credit/GDP \% } & Mean & 129 & 143 & 145 & 129 & 141 \\
\hline & Std dev. & 61.5 & 56.6 & 69.1 & 70.6 & 56.3 \\
\hline & Median & 104 & 121 & 139 & 104 & 121 \\
\hline
\end{tabular}

\footnotetext{
${ }^{6}$ We use the employment in the subsidiary $E i$ and the total consolidated employment, $E_{T}$ to determine the firm's $Q_{j}$ which we call parent's $Q$, but really refers to the $Q$ of the entire entity except the subsidiary. The firm's consolidated $Q$ is $Q_{T}=\left(\left(Q_{i}{ }^{*} E_{i}+Q_{j}{ }^{*} E_{j}\right) / E_{T}\right)$. So parent's $Q$ is $Q_{j}=\left(Q_{T}{ }^{*} E_{T}-Q_{i}{ }^{*} E_{i}\right) / E_{j}$.
} 
We use financial information about the subsidiary (sales growth, cash flow, and Tobin's $Q$ ) as controls alongside our variable of interest. These variables are subject to endogeneity concerns in the empirical $Q$ model, so we are careful about our interpretation of their coefficients. Liquidity can be calculated in two different ways, either as a stock of cash or as cash flow. The flow measure has proved to be the empirically more successful proxy for liquidity in the past (Devereux and Schiantarelli, 1989). Hence, we use cash flow as a proxy for the liquidity constraints of the firm. In accordance with our procedure with respect to investment, we adjust for size and inflation by dividing cash flow by total assets at the start of the year. ${ }^{7}$

\section{The sample of listed subsidiaries}

We are concerned that our results for listed firms may not be easily generalized to the broader population of multinational subsidiaries. Table IV provides summary information about the characteristics of listed and unlisted subsidiaries of a sub-sample of the firms in our sample. The subsample comprises all of the firms - a total of 51 - that are parents of at least one of the top 2,000 listed companies and at least one of the top 2,000 unlisted companies in Western Europe. These data show that parents typically have over 50\% more unlisted than listed subsidiaries. The listed subsidiaries are larger in terms of both assets and employment. The median ownership stake of the parent of unlisted subsidiaries is $100 \%$ and $57 \%$ for listed subsidiaries. In general the comparison suggests that listed subsidiaries are larger and more independent than their unlisted counterparts. This indicates that our choice of sample makes it less likely that we would observe an effect of parental control on the investment decisions of the subsidiary - so any bias introduced by our sample is likely to make it harder for us to identify an effect.

\footnotetext{
7 There is an active debate as to whether the significance of cash flow terms in investment equations can be interpreted as evidence of financing constraints. Based on firms' annual reports and managements' discussions of liquidity requirements, Kaplan and Zingales (1997) conclude that it cannot while Fazzari, Hubbard and Petersen (2000) contend that Kaplan and Zingales' methodology is flawed. Gomes (2001) argues that the presence of cash flow variables in investment equations is neither a necessary nor sufficient condition for capital market imperfections. They are not necessary since financial constraints should be reflected in firm valuations and therefore in marginal $Q$ and they are not sufficient because non-linearities may be captured by cash flow in linear investment equations. Cooper and Ejarque (2001) demonstrate that the inclusion of profit variables may reflect market power rather than capital market imperfections in investment equations that use average in place of marginal $Q$. For this reason we are cautious in the following analysis about interpreting cash flow variables as evidence of financing constraints. We return to these issues in the discussion of our econometric strategy in Section 3.
} 
Table IV. Comparison between listed and unlisted subsidiaries

The sample includes all the listed and unlisted subsidiaries of a subsample of parents firms (51 of them), where those parents are all the firms whose subsidiaries include at least one of the top 2,000 listed companies and at least one of the top 2,000 unlisted companies in Western Europe only. Employees is Datastream item WC07011. Share of ownership is the stock holding of the largest owner reported by the subsidiary.

\begin{tabular}{|c|c|c|c|}
\hline & & $\begin{array}{c}\text { Listed } \\
\text { Subsidiaries }\end{array}$ & $\begin{array}{c}\text { Unlisted } \\
\text { Subsidiaries }\end{array}$ \\
\hline Number of subsidiaries in this sample & Mean & 1.37 & 2.16 \\
\hline \multirow[t]{3}{*}{ Total Assets (USD millions) } & Mean & 12 & 5 \\
\hline & $\begin{array}{l}\text { Std. } \\
\text { dev. }\end{array}$ & 29 & 5 \\
\hline & Median & 4 & 3 \\
\hline \multirow[t]{3}{*}{ Employment } & Mean & 31,583 & 13,995 \\
\hline & $\begin{array}{l}\text { Std. } \\
\text { dev. }\end{array}$ & 54,700 & 9,175 \\
\hline & Median & 13,352 & 11,143 \\
\hline \multirow{3}{*}{ Share of ownership (\%) } & Mean & 55.2 & 95.9 \\
\hline & $\begin{array}{l}\text { Std. } \\
\text { dev. }\end{array}$ & 22 & 14.1 \\
\hline & Median & 57 & 100 \\
\hline
\end{tabular}

Affiliate firms may benefit from liquidity spillovers in their internal capital markets. Improved access to internal capital markets may increase financing flexibility. There may be 'more money' available if integration leads to a larger total entity, which can raise more external finance than could the individual entities themselves. Table $\mathrm{V}$ compares a number of characteristics of subsidiaries and their parents. Although cash flow and investment relative to total assets are virtually identical in parent firms and their subsidiaries, the total assets of parent firms are more than ten times as large. 
Table V. Comparison between subsidiaries and their owners

Investment on total assets is Datastream item 08416 Asset Utilization Ratio measured as the annual item Capital Expenditures / (Total Assets - Customer Liabilities on Acceptances). Cash-flow is Datastream item 04860 (Net cash flow from operating activities) divided by total assets. Stock Market Size is the ratio of the total market value of listed companies to GDP from the World Bank.

\begin{tabular}{lrr}
\hline \hline & & \\
& \multicolumn{1}{c}{ Parent } & \multicolumn{1}{c}{ Subsidiary } \\
\cline { 2 - 3 } Investment/Total Assets & 0.0555 & 0.0581 \\
Cash flow/Total Assets & 0.0924 & 0.0928 \\
Total Assets (USD millions) & 23 & 2 \\
Cash flow (USD) & 938,883 & 107,047 \\
Stock Market Size in Parent or & 58.2 & 55 \\
Subsidiary Country (\% GDP) & &
\end{tabular}

\section{Subsidiary investment and parent investment opportunities}

We examine whether the parent's investment opportunities influence the investment of the subsidiary. To do this, we use the following specification

(1) $\quad \operatorname{Inv}_{i t}=a_{0}+a_{1} Q_{j t}+a_{2} X_{i t}+a_{3} X_{j t}+u_{i}+v_{t}+e_{i t}$

where the parent firm of subsidiary $i$ is designated by subscript $j$ and where $\operatorname{In} v_{i t}$ is capital expenditure divided by total assets for subsidiary i, i.e. $\operatorname{In} v_{i t} \equiv I_{i t} / K_{i, t-1} ; X_{i t}$ is a vector of financial variables for the subsidiary including $Q_{i t}$, Tobin's $Q$ ratio, i.e. market value of assets divided by the book 
value; $C F_{i t}$ denotes firm $i$ 's cash flow divided by its total assets; $S G_{i t}$ is the sales growth for firm $i{ }^{8} X_{j t}$ is a vector of financial variables for the parent including $C F_{j t}$ denotes firm j's cash flow divided by its total assets. The firm fixed effect is $u_{i}$ and the time dummy is $v_{t}$.

Our coefficient of interest is $a_{l}$ which describes the role of parent investment opportunities in the investment of the subsidiary. We use firm fixed effects estimation, which means that the experiment we are considering is how a shock to the parent firm's $Q$ affects its subsidiary's investment, controlling for the subsidiary's investment opportunities. If the subsidiary can borrow at a lower cost of capital from the parent firm, this will already be incorporated in the subsidiary's $Q$. Given that we can control for $Q_{i}$, we can identify the impact on subsidiary investment of new information that affects $Q_{j}$ making investment outcomes for the parent more attractive.

Thus if the internal capital market actively reallocates funds across related entities then we expect the affiliate's investment to be decreasing in the parent's $Q$, holding the affiliate's $Q$ and other financial variables constant. Since we observe the cash flow and $Q$ of both parent and subsidiary, we are able to test directly for effects consistent with the presence of a financing relationship between them.

Table VI indicates that the parent's $Q$ has a significant negative effect. As predicted by the efficient internal capital market or 'internal Darwinism' argument and contrary to the 'internal socialism' argument, an increase in the parent's $Q$ leads to a reduction in the subsidiary's investment. This result is statistically and economically significant. For example, in Column 2, a shift in parent's $Q$ from the $25^{\text {th }}$ percentile $(0.81)$ to the $75^{\text {th }}$ percentile (2.63) involves a change in the subsidiary investment/total assets of -0.0018 . This represents a reduction of $5 \%$ over the median subsidiary investment/total assets $(0.036)$.

\footnotetext{
${ }^{8}$ Since firms typically operate under conditions of imperfect competition in the product market, it is appropriate to augment the usual $Q$ equation with sales growth to capture the impact on investment of a shift in the demand curve. The firm fixed effect is $u_{i}$ and the time dummy is $v_{t}$.
} 
Table VI. Regression of Investment by Subsidiaries on Parent's Tobin's $Q$

This table reports the results from regressions of the subsidiary's capital investment / total assets on the indicated explanatory variables. Columns 1 to 4 are estimated by OLS with firm fixed effects and year dummies. Column 3 also includes 2-digit industry dummies interacted with time. R2 is the 'within' R2. Column 5 uses IV with parent Q instrumented with a binary variable indicating the existence of a recession in the parent country. Robust standard errors are reported beneath the coefficients. $* * * 1 \% ; * * 5 \%$ and $* 10 \%$ level of significance.

\begin{tabular}{|c|c|c|c|c|c|}
\hline \multirow[t]{2}{*}{ Variable } & $\begin{array}{c}\text { All } \\
\text { subsidiaries }\end{array}$ & $\begin{array}{c}\text { All } \\
\text { subsidiaries }\end{array}$ & $\begin{array}{c}\text { All } \\
\text { subsidiaries }\end{array}$ & $\begin{array}{l}\text { Matched to } \\
\text { surrogate } \\
\text { parent }\end{array}$ & IV \\
\hline & $(1)$ & (2) & (3) & (4) & (5) \\
\hline$Q_{j}$ & $\begin{array}{c}-0.0008 \\
{[0.0004]^{* *}}\end{array}$ & $\begin{array}{c}-0.0010 \\
{[0.0005]^{* *}}\end{array}$ & $\begin{array}{c}-0.0006 \\
{[0.0003]^{* * *}}\end{array}$ & $\begin{array}{c}0.0001 \\
{[0.0005]}\end{array}$ & $\begin{array}{c}-0.0101 \\
{[0.007]^{* *}}\end{array}$ \\
\hline $\begin{array}{l}\text { Subsidiary controls } \\
S G_{i}\end{array}$ & & $\begin{array}{c}0.0058 \\
{[0.001]^{* * *}}\end{array}$ & $\begin{array}{c}0.0082 \\
{[0.001]^{* * *}}\end{array}$ & $\begin{array}{c}0.0053 \\
{[0.0011]^{* * *}}\end{array}$ & $\begin{array}{c}0.004 \\
{[0.000]^{* * *}}\end{array}$ \\
\hline$C F_{i}$ & & $\begin{array}{c}0.0445 \\
{[0.0046] * * *}\end{array}$ & $\begin{array}{c}0.041 \\
{[0.0046]^{* * *}}\end{array}$ & $\begin{array}{c}0.0452 \\
{[0.0054]^{* * *}}\end{array}$ & $\begin{array}{c}0.047 \\
{[0.002] * * *}\end{array}$ \\
\hline$Q_{i}$ & & $\begin{array}{c}0.0082 \\
{[0.0003]^{* * *}}\end{array}$ & $\begin{array}{c}0.0066 \\
{[0.0003]^{* * *}}\end{array}$ & $\begin{array}{c}0.0084 \\
{[0.0004]^{* * *}}\end{array}$ & $\begin{array}{c}0.0083 \\
{[0.000]^{* * *}}\end{array}$ \\
\hline $\begin{array}{l}\text { Parent controls } \\
C F_{j}\end{array}$ & & $\begin{array}{c}0.0068 \\
{[0.0119]}\end{array}$ & $\begin{array}{c}0.0072 \\
{[0.0111]}\end{array}$ & $\begin{array}{c}0.0039 \\
{[0.0124]}\end{array}$ & $\begin{array}{c}0.018 \\
{[0.013]}\end{array}$ \\
\hline Constant & $\begin{array}{c}0.0512 \\
{[0.0006]^{* * * *}}\end{array}$ & $\begin{array}{c}0.0346 \\
{[0.0006]^{* * * *}}\end{array}$ & $\begin{array}{c}0.0436 \\
{[0.0009]^{* * *}}\end{array}$ & $\begin{array}{c}0.0345 \\
{[0.0007]^{* * *}}\end{array}$ & $\begin{array}{c}0.0334 \\
{[0.001]^{* * *}}\end{array}$ \\
\hline $\begin{array}{l}\text { Firm effects } \\
\text { Time effects }\end{array}$ & $\begin{array}{l}\mathrm{Y} \\
\mathrm{Y}\end{array}$ & $\begin{array}{l}\mathrm{Y} \\
\mathrm{Y}\end{array}$ & $\begin{array}{l}\mathrm{Y} \\
\mathrm{Y}\end{array}$ & $\begin{array}{l}\mathrm{Y} \\
\mathrm{Y}\end{array}$ & $\begin{array}{l}\mathrm{Y} \\
\mathrm{Y}\end{array}$ \\
\hline Industry $\mathrm{x}$ Time effects & & & $\mathrm{Y}$ & & \\
\hline No. obs. & 29878 & 29878 & 29878 & 24040 & 23813 \\
\hline $\mathrm{R}^{2}$ & 0.012 & 0.035 & 0.062 & 0.033 & 0.01 \\
\hline \multicolumn{6}{|l|}{ First stage: } \\
\hline $\begin{array}{l}\text { Recession in parent } \\
\text { country }\end{array}$ & & & & & $\begin{array}{c}-0.159 \\
{[0.006]^{* * *}}\end{array}$ \\
\hline F-Test on exclusion: & & & & & 18.96 \\
\hline
\end{tabular}




\section{Endogeneity}

There is scope for concern that parent's $Q$ is affected by the investment of the subsidiary or that both are affected by some third variable for which we have not controlled. We take the following steps to mitigate this potential endogeneity problem. First, as described in Section I, we measure parent's $Q$ by subtracting the subsidiary component from consolidated $Q$. In this way we remove the direct effect of the subsidiary from parent $Q$.

Nevertheless, it is still possible for changes in the investment of the subsidiary to be indirectly correlated with parent's $Q$. For example, the investment of the subsidiary may be a leading indicator of a shock that could affect the investment opportunities of the whole multinational network. There are several reasons to believe that our results are not invalidated by such effects. First many of the conceivable shocks that may jointly affect parent's $Q$ and subsidiary investment would be likely to affect them in the same direction, making it less likely that we would find a negative relationship in our results. Second, there is little correlation between subsidiary and parent cash flow, $Q$ or investment (see Table VII). Had there been a correlation then the negative relation between parent $Q$ and subsidiary investment might have reflected the effect of omitted variables. Third as reported in Table IV, the average size of parents is an order of magnitude larger than that of subsidiaries.

Table VII. Correlation between subsidiaries and their parents

This table reports correlations between the listed variables. Investment on total assets is Datastream item 08416 Asset Utilization Ratio measured as the annual item Capital Expenditures / (Total Assets - Customer Liabilities on Acceptances). Cash-flow is Datastream item 04860 (Net cash flow from operating activities) divided by total assets. Q is the share price divided by the book value per share (Datastream PTBV). Sales growth is the log difference in sales in US\$ from Datastream item number 07240.

\begin{tabular}{lccccc}
\hline \hline & $\begin{array}{c}\text { Inv/TA } \\
\text { (Subs.) }\end{array}$ & $\begin{array}{c}\text { Cash } \\
\text { Fl./TA } \\
\text { (Subs.) }\end{array}$ & $\begin{array}{c}\text { Sales gr. } \\
\text { (Subs.) }\end{array}$ & $\begin{array}{c}\text { Cash } \\
\text { Fl/TA } \\
\text { (Parent) }\end{array}$ & $\begin{array}{c}\text { Q } \\
\text { (Subs.) }\end{array}$ \\
\cline { 2 - 6 } Investment/TA (Subsidiary) & 1 & & & & \\
Cash Flow/TA (Subsidiary) & 0.3261 & 1 & & & \\
Sales growth (Subsidiary) & 0.0978 & 0.2009 & 1 & & \\
Cash Flow/TA (Parent) & 0.0146 & 0.0033 & -0.0011 & 1 & \\
Q (Subsidiary) & 0.1649 & 0.1994 & 0.135 & -0.0043 & 1 \\
Q (Parent) & 0.0119 & 0.0034 & 0.0017 & 0.5691 & 0.0073 \\
& & & & & \\
\hline
\end{tabular}


Whilst these arguments suggest that any bias is likely to attenuate our estimate of a 'negative parent $Q$ effect', our data allows us to carry out a series of more systematic checks for the presence of omitted variable and endogeneity problems. In Column 3 of Table VI we approach the issue in another way by running the regression from Column 2 augmented by interactions between the 2-digit industry of the firm and the year. The inclusion of the additional dummies does not affect the results. In addition, following the work of Abel and Eberly (1996) on non-convex adjustment costs, we checked to see if higher orders of $Q$ are significant in the investment equation but we found that they are not.

In Column 4 we examined whether the relationship between the parent's performance and the subsidiary's investment reflected general influences (for example macroeconomic conditions) on the total population of subsidiaries and parents rather than specific internal market relations between the parents and subsidiaries in question. We did this by constructing a matched sample of surrogate parent firms in the same industry and country as the actual parents that are closest in size to the real parents. ${ }^{9}$ In Column 4 of Table VI we find that there is no significant influence of the surrogate parent $Q$ on the subsidiary's investment.

In Column 5 we instrument parent's $Q$ using a binary variable indicating the presence of a recession in the parent's country on the assumption that a macro shock in the parent country will affect the parent firm's $Q$ but will not directly affect the subsidiary's investment. ${ }^{10}$ As explained in the Data Appendix, we use quarterly GDP data to identify recession periods in our data. The validity of the instrument is supported by the first stage results: the coefficient on the recession variable in the first stage indicates that a recession in the parent country reduces the parent $Q$ by 0.16 . The first stage $\mathrm{F}$ test of the significance of the excluded instrument is $18.96 .{ }^{11}$ Column 5 reports that the coefficient on parent's $Q$ in the IV specification remains negative and significant. The (absolute) value of the coefficient is significantly larger than in the OLS estimation, which is consistent with the presence of measurement

\footnotetext{
${ }^{9}$ Our matching exercise was conducted simply by ordering the parent firms by their country, industry, and size. We then matched each subsidiary to the parent firm which was nearest its own parent.

${ }^{10}$ Note that the correlation between our parent recession variable and subsidiary investment is low (0.018).

${ }^{11}$ This exceeds the critical value of 16.38 for the Stock and Yogo (2003) weak-instrument test for 2SLS with exact identification and one endogenous regressor. The hypothesis of a weak instrument is rejected using their most stringent criterion.
} 
error in $Q .{ }^{12}$ This suggests that the economic significance of the parent $Q$ effect reported above based on the OLS estimates is likely to be a lower bound.

In Table VIII we do some additional robustness checks to test whether particular sub-samples of firms are driving the result, we repeat the base-line regression (Col. 2 of Table VI) for the sample of foreign-owned firms excluding US firms both as owners and as subsidiaries (reported in Col. 1 of Table VIII). The results remain unchanged. We also split the sample between firms whose principal activity is in manufacturing and those with a non-manufacturing core. The results for manufacturing firms were similar to those for the full sample (Col. 2).

Table VIII. Robustness: Non-US Firms and Manufacturing Firms and Stand-Alone Firms

This table reports the results from regressions of the subsidiary's capital investment / total assets on the indicated explanatory variables. Columns 1 to 4 are estimated by OLS with firm fixed effects and year dummies. R2 is the 'within' R2. Robust standard errors are reported beneath the coefficients. *** $1 \%$; $* * 5 \%$ and $* 10 \%$ level of significance.

\begin{tabular}{|c|c|c|c|c|}
\hline Variable & $\begin{array}{c}\text { Non-US firms } \\
\text { (1) }\end{array}$ & $\begin{array}{l}\text { Manufacturing } \\
\text { firms } \\
\text { (2) } \\
\end{array}$ & $\begin{array}{c}\text { All } \\
\text { subsidiaries } \\
(3) \\
\end{array}$ & $\begin{array}{c}\text { All stand-alone } \\
\text { firms } \\
(4) \\
\end{array}$ \\
\hline$Q_{j}$ & $\begin{array}{c}-0.001 \\
{[0.0005]^{* * *}}\end{array}$ & $\begin{array}{c}-0.0016 \\
{[0.0005]^{* * *}}\end{array}$ & & \\
\hline $\begin{array}{l}\text { Subsidiary controls } \\
S G_{i}\end{array}$ & $\begin{array}{c}0.0065 \\
{[0.001]^{* * *}}\end{array}$ & $\begin{array}{c}0.0037 \\
{[0.0015]^{* * *}}\end{array}$ & $\begin{array}{c}0.0057 \\
{[0.0009]^{* * *}}\end{array}$ & $\begin{array}{c}0.0039 \\
{[0.0005]^{* * *}}\end{array}$ \\
\hline$C F_{i}$ & $\begin{array}{c}0.0446 \\
{[0.0048]^{* * *}}\end{array}$ & $\begin{array}{c}0.0516 \\
{[0.0064]^{* * *}}\end{array}$ & $\begin{array}{c}0.0446 \\
{[0.0046]^{* * *}}\end{array}$ & $\begin{array}{c}0.0488 \\
{[0.0025]^{* * *}}\end{array}$ \\
\hline$Q_{i}$ & $\begin{array}{c}0.0082 \\
{[0.0003]^{* * *}}\end{array}$ & $\begin{array}{c}0.0082 \\
{[0.0005]^{* * *}}\end{array}$ & $\begin{array}{c}0.0081 \\
{[0.0003]^{* * *}}\end{array}$ & $\begin{array}{c}0.0075 \\
{[0.0001]^{* * *}}\end{array}$ \\
\hline $\begin{array}{l}\text { Parent controls } \\
C F_{j}\end{array}$ & $\begin{array}{c}0.0184 \\
{[0.0147]}\end{array}$ & $\begin{array}{l}-0.0047 \\
{[0.0182]}\end{array}$ & & \\
\hline Constant & $\begin{array}{c}0.0344 \\
{[0.0007]^{* * *}}\end{array}$ & $\begin{array}{c}0.0379 \\
{[0.0009]^{* * *}}\end{array}$ & $\begin{array}{c}0.034 \\
{[0.001]^{* * *}}\end{array}$ & $\begin{array}{c}0.032 \\
{[0.000]^{* * *}}\end{array}$ \\
\hline $\begin{array}{l}\text { Firm effects } \\
\text { Time effects }\end{array}$ & $\begin{array}{l}\mathrm{Y} \\
\mathrm{Y}\end{array}$ & $\begin{array}{l}\mathrm{Y} \\
\mathrm{Y}\end{array}$ & $\begin{array}{l}\mathrm{Y} \\
\mathrm{Y}\end{array}$ & $\begin{array}{l}Y \\
Y\end{array}$ \\
\hline No. obs. & 28152 & 13798 & 29878 & 100330 \\
\hline $\mathrm{R}^{2}$ & 0.0356 & 0.0382 & 0.0348 & 0.0337 \\
\hline
\end{tabular}

\footnotetext{
${ }^{12}$ Previous studies that correct for measurement error in $Q$ find that the size of the coefficient goes up substantially as compared with the OLS estimate. The increase that we find lies within the range reported for own $Q$ estimates in Cummins, Hassett and Hubbard (1996), Erickson and Whited (2000) and Bond and Cummins (2001).
} 
In addition we compare our sample of subsidiaries (owned firms) with the remaining (stand alone) firms in the population of listed firms. We repeat our basic regression excluding the parent variables on the main sample of subsidiaries (Col. 3) and compare this with the group of stand alone firms (Col. 4). We find evidence that the stand-alone firms are less responsive to their own investment opportunities, as reflected by the smaller coefficient on the Tobin's $Q$ coefficient. This is suggestive evidence that parents weaken the financing constraints of their subsidiaries. Although the coefficients on $Q$ in columns 3 and 4 are statistically different at the $1 \%$ level, we are reluctant to over interpret this result because firms are not randomly allocated between subsidiary and stand-alone status.

\section{Interpretation}

The above results on multinationals are consistent with the view that foreign parents reallocate funds globally across subsidiary entities according to an efficient operation of internal capital markets. They stand in contrast to the weight of evidence in the literature on diversified firms which suggests that, on average, diversified firms engage in internal socialism among their divisions (Shin and Stultz, 1998, Scharfstein, 1998, Rajan, Servaes and Zingales, 2000, surveyed in Stein, 2003). ${ }^{13}$

Doubt has been cast on the conclusion of 'internal socialism' by the finding that in financially unrelated firms that are known to merge later, a similar relationship to that in Shin and Stulz between the cash flow of one firm and the investment of the other is found (Chevalier, 2004). Furthermore, the crosssubsidisation conclusion has emerged from a methodology that is vulnerable to two related problems. It assumes that the divisions of conglomerate firms are allocated randomly to parent firms and that they are drawn randomly from the same distribution as stand-alone firms. On the basis of these assumptions, the

\footnotetext{
${ }^{13}$ Rajan, Servaes and Zingales (2000) compare the investment of divisions of diversified conglomerates with investment by stand-alone firms. They find that divisions in industries with low investment prospects (measured by average industry $Q$ ratios) invest more than stand-alone firms in the same industry, and divisions with high investment prospects invest less than their stand-alone counterparts. Scharfstein (1998) shows that the sensitivity of investment to industry $Q$ is much lower for conglomerate divisions than for stand-alone firms.
} 
average industry (segment) $Q$ serves as a reliable proxy for the division's investment opportunities. ${ }^{14}$ However if the diversification decision is endogenous, then conglomerate divisions are systematically different from stand-alone firms and industry $Q$ 's may not be good proxies for the opportunities of conglomerate divisions (Whited, 2001). ${ }^{15}$ Chevalier (2004) looks at the investment activity of firms in the period before they merge into a single entity. She finds that investment patterns that have been attributed to cross-subsidisation are visible in the behaviour of pre-merger firms (i.e. that are not financially related), suggesting that some of the cross-subsidisation results in the literature may be attributable to selection bias. $^{16}$

In the sample of conglomerate firms we investigate in this paper, the divisions (known more familiarly as 'subsidiaries' in this context) are separately listed firms so we observe the Tobin's $Q$ of each entity directly. We therefore avoid the central empirical problem of the previous literature that the observed differences in the investment of divisions and stand-alone firms are the consequence of their different investment opportunities rather than their different financing options.

Of course the financing relationship between a domestic owner or a multinational headquarters and its listed subsidiaries is different from the relationship between a conglomerate and its divisions. As noted in Section I, we drop from our sample subsidiaries that have changed ownership recently, mitigating the selection problem associated with the use of spin-offs. Listed subsidiaries are, by their nature, not

\footnotetext{
14 The average Tobin's $Q$ of stand-alone firms in an industry provides a reasonable proxy for the investment opportunities of a division of a conglomerate in the same industry if, as has been suggested, industry effects account for much of the variation in Tobin's $Q$ (Stein 2003).

${ }^{15}$ Maksimovic and Phillips (2002) argue that a firm's diversification is an endogenous decision determined by the underlying characteristics of the pre-merger firms. Graham, Lemmon and Wolf (2002) argue that stand-alone firms are systematically different from divisions of conglomerate firms in the same industry.

${ }^{16}$ In an attempt to circumvent this problem, Gertner, Powers and Scharfstein (2002) investigate the investment behaviour of firms that are spun off from a conglomerate. They observe that once a division is spun off from its parent, its investment responds more sensitively to industry $Q$, from which they infer inefficiency in the conglomerate. Çolak and Whited (2005) take issue with this approach and demonstrate that contrary to claims that it provides a clean test of the efficiency of internal capital markets, the results are contaminated by the presence of selection bias and measurement error. The decision to spin off a division is not a random one: a division is likely to be spun off only in cases where the combined entity is less valuable than the sum of its parts. Thus while the results in the 'spin off' papers provide evidence of inefficient overinvestment in their samples, it almost certainly presents a biased picture of the efficiency of internal capital markets in the population of conglomerates. Similar methodological problems have plagued the parallel literature on the costs or benefits of group membership of Japanese keiretsu. Early studies such as Hoshi, Kashyap and Scharfstein, 1991 and Prowse 1992 identified benefits of membership whereas more recent ones (e.g. Weinstein and Yafeh, 1998 and Morck and Nakamura, 1999) have identified costs. In a recent study of Korean chaebols, Ferris, Kim and Kitsabunnarat (2003) argue in favour of the inefficiency of the chaebol using a methodology similar to that criticized by Çolak and Whited.
} 
wholly owned by their parents; and this lower concentration of ownership may cause managers of listed subsidiaries to have a higher degree of autonomy than divisional managers. We may therefore be less likely to observe evidence consistent with an internal capital market than would be the case in less independent subsidiaries. To minimise this difference, we restrict our sample to listed subsidiaries which report a 'global ultimate' - a particularly strong parental relationship, which requires an ownership stake of the parent of more than $50 \%$. Our result that there is a financial relationship between parent and subsidiary extends the evidence on the presence of an internal capital market within divisional firms to listed multinational firms.

In the next section we exploit variations in our sample to investigate whether those foreign subsidiaries that are most like divisions of domestic conglomerates in the existing literature exhibit more evidence of internal socialism than our results on average. Since the firms in our sample encompass a range of ownership stakes of the parent between $50 \%$ and $100 \%$ and varying degrees of geographic proximity, we can see whether the financing relationship changes as a foreign listed subsidiary becomes more like a wholly owned domestic division.

\section{Are distant parents less strict on their subsidiaries?}

The results above suggest that internal capital markets exist in our sample of multinational firms: finance is being allocated in response to the relative profitability of projects within the group. Our sample is a convenient setting in which to analyse the operation of internal capital markets in more depth. We investigate how the extent of reallocation is affected by characteristics of the parent-subsidiary relationship. In particular we are interested in whether our results are diminished in relationships which are more likely to invite influence activities.

Much of the theoretical work on the 'dark side' of internal capital markets considers the presence of influence activities that may arise in the relationship between managers and the CEO. Several papers have addressed the question of why such behaviour may distort the CEO's capital budget decision, rather 
than just affect the distribution of managerial compensation. ${ }^{17}$ Scharfstein and Stein (2000) consider the case where the CEO is herself an agent and finds it more attractive to compensate the managers of poorly performing divisions with greater investment rather than with cash, which the CEO would prefer to reserve for alternative uses. Stein (2003) cites the example of the successful diversified conglomerate, General Electric, whose policy of rotating its managers between divisions has the benefit of reducing managers' incentives to lobby for excess capital.

The effect of influence costs on the internal capital market of multinational firms suggests that when subsidiaries are more proximate to their parent firms, we may expect the reallocation which we observe in our main results to be reduced. We measure proximity in terms of both the geographic distance between parent and subsidiary, and the strength of the management relationship which we proxy by the size of the parent's stake in the subsidiary.

If influence costs are present then proximity may worsen the efficiency with which internal capital markets allocate funds to subsidiaries. However for other reasons proximity may improve internal capital markets by improving the information on which reallocation is based, or strengthening the control with which it is mandated. Theories that emphasize the 'bright side' of internal capital markets focus on the information and control advantages afforded to the CEO as a provider of internal finance over the providers of external finance. This theory rests on the superior ability of the CEO to pick winners from among her business units as discussed in Gertner, Scharfstein and Stein (1994) and Li and Li (1996). This is likely to be improved when the subsidiary is nearby and when the owner has a large stake.

Thus the effect of proximity on internal capital markets involves a trade-off between the potentially positive effects of information and deleterious effects of influence. If parents in close proximity are able to overcome capital market imperfections better than parents at a distance then more concentrated ownership and closer parents should be associated with a more negative relationship to parents' $Q$. If the influence of the parent is to the detriment of the subsidiary, and this increases more with

\footnotetext{
${ }^{17}$ Rajan, Servaes and Zingales (2000) suggests that 'socialism', i.e. a more equal allocation of resources among divisions, might increase incentives for division managers to cooperate and reduce rent-seeking behaviour.
} 
proximity than do the beneficial effects of increased information, then we would expect proximity to decrease the effect of parent's $Q$ on the investment of the subsidiary.

Column 1 of Table IX reports the effects of concentration of ownership of the parent on the investment of the subsidiary. The interactive effect of the ownership stake of the largest owner on the foreign owners' $Q$ and cash flow are reported. The negative $Q$ effect of the parent diminishes with the size of the largest foreign ownership. Thus the internal capital market is stronger (exhibiting more reallocation in response to changes in investment opportunities) when the parent less tightly controls its subsidiary. ${ }^{18}$

In Column 2, we report the impact of distance from the parent on the investment of its subsidiary for the sample of foreign-owned firms. We find that the effect of the parent's $Q$ becomes more negative as distance increases. Consistent with influence effects dominating information effects this suggests that investment in subsidiaries of more distant firms is more sensitive to their parent's investment opportunities. Increased investment opportunities for the headquarters are more likely to result in reduced investment by the subsidiary when the subsidiary is located further from the parent. We interpret this as evidence that the loss of information is outweighed by the benefits of reduced influence. The CEO is less susceptible to influence activities from more remote managers, with whom she has a more 'arms length' relationship as a result of greater geographical distance and a smaller ownership stake. The results in Table IX suggest that the failure to find a significant effect of parent cash flow on subsidiary investment in the basic regression in Table VI reflects heterogeneity in the sample. Once the proximity measures of ownership concentration or distance are introduced, the parent's cash flow becomes significant.

\footnotetext{
${ }^{18} \mathrm{We}$ find the same results for ownership concentration for the sample of subsidiaries with domestic rather than foreign owners.
} 
Table IX: Ownership Concentration, Distance and Financial Development

This table reports the results from regressions of the subsidiary's capital investment / total assets on the indicated explanatory variables. Columns 1 to 3 are estimated by OLS with firm fixed effects and year dummies. Investment on total assets is Datastream item 08416 Asset Utilization Ratio measured as the annual item Capital Expenditures / (Total Assets - Customer Liabilities on Acceptances). Cash-flow is Datastream item 04860 (Net cash flow from operating activities) divided by total assets. Q is the share price divided by the book value per share (Datastream PTBV). Sales growth is the log difference in sales in US\$ from Datastream item number 07240. Distance to owner is the great circle distance between capital cities of the two countries measured as a percentage of half the earth's circumference (i.e. $\max$ is 100). Private Credit is the ratio of private credit to GDP from the World Bank. R2 is the 'within' R2. Robust standard errors are reported beneath the coefficients. *** $1 \%$; ** 5\% and * $10 \%$ level of significance.

\begin{tabular}{|c|c|c|c|}
\hline & $\begin{array}{c}\text { Foreign-owned } \times \\
\text { ownership } \\
\text { concentration } \\
(1) \\
\end{array}$ & $\begin{array}{c}\text { Foreign-owned } \times \\
\text { distance } \\
(2) \\
\end{array}$ & $\begin{array}{l}\text { Foreign-owned } \times \\
\text { financial development } \\
\text { (3) }\end{array}$ \\
\hline$Q_{j}$ & $\begin{array}{c}-0.0012 \\
{[0.0004]^{* * * *}}\end{array}$ & $\begin{array}{c}0.0001 \\
{[0.0001]}\end{array}$ & $\begin{array}{c}0.0008 \\
{[0.0008]}\end{array}$ \\
\hline$Q_{j} \times \operatorname{Conc}_{j}$ & $\begin{array}{c}0.0003 \\
{[0.0001]^{* * *}}\end{array}$ & & \\
\hline$Q_{j} \times D i s t_{j}$ & & $\begin{array}{c}-0.0019 \\
{[0.0007] * * *}\end{array}$ & \\
\hline$Q_{j} \times$ PrivCred $_{i j}$ & & & $\begin{array}{c}-0.0017 \\
{[0.0006]^{* *}}\end{array}$ \\
\hline $\begin{array}{l}\text { Subsidiary controls } \\
S G_{i}\end{array}$ & $\begin{array}{c}0.0069 \\
{[0.0022]^{* * *}}\end{array}$ & $\begin{array}{c}0.0067 \\
{[0.0018]^{* * *}}\end{array}$ & $\begin{array}{c}0.0057 \\
{[0.0018]^{* * *}}\end{array}$ \\
\hline$C F_{i}$ & $\begin{array}{c}0.0457 \\
{[0.0115]^{* * *}}\end{array}$ & $\begin{array}{c}0.0443 \\
{[0.0089]^{* * *}}\end{array}$ & $\begin{array}{c}0.0444 \\
{[0.0088]^{* * *}}\end{array}$ \\
\hline$Q_{i}$ & $\begin{array}{c}0.0097 \\
{[0.0007]^{* * *}}\end{array}$ & $\begin{array}{c}0.0086 \\
{[0.0006]^{* * *}}\end{array}$ & $\begin{array}{c}0.0087 \\
{[0.0006]^{* * *}}\end{array}$ \\
\hline $\begin{array}{l}\text { Parent controls } \\
C F_{j}\end{array}$ & $\begin{array}{c}0.0232 \\
{[0.0139]^{*}}\end{array}$ & $\begin{array}{c}0.0463 \\
{[0.0226]^{* * *}}\end{array}$ & $\begin{array}{c}0.0585 \\
{[0.0263]^{* *}}\end{array}$ \\
\hline$C F_{j} \times$ Conc $_{j}$ & $\begin{array}{c}-0.0029 \\
{[0.0015]^{*}}\end{array}$ & & \\
\hline$C F_{j} \times D i s t_{j}$ & & $\begin{array}{c}-0.0011 \\
{[0.0005]^{* * *}}\end{array}$ & \\
\hline$C F_{j} \times$ PrivCred $_{i j}$ & & & $\begin{array}{c}-0.0377 \\
{[0.0177]^{* *}}\end{array}$ \\
\hline Constant & $\begin{array}{c}0.0354 \\
{[0.0016]^{* * *}}\end{array}$ & $\begin{array}{c}0.0348 \\
{[0.0013]^{* * *}}\end{array}$ & $\begin{array}{c}0.0352 \\
{[0.0012]^{* * *}}\end{array}$ \\
\hline Firm effects & Y & $\mathrm{Y}$ & Y \\
\hline Time effects & Y & $\mathrm{Y}$ & $\mathrm{Y}$ \\
\hline $\mathrm{N}$ & 6798 & 9087 & 6283 \\
\hline R2 & 0.0464 & 0.0378 & 0.0323 \\
\hline
\end{tabular}


To summarize, the internal capital market is stronger (exhibiting more reallocation in response to changes in investment opportunities) when the firms are more distant or the owner's stake is smaller (although above 50\%). We interpret this as supporting the primacy of influence costs over information effects. The presence of other owners or lower geographical proximity serves to distance the CEO of the parent firm from the managers of the subsidiary. The costs of lower information appear to be outweighed by the benefits of reduced influence effects.

The fact that distance and dispersal of ownership exert a beneficial influence on internal capital markets may help to explain differences in results in multinational firms from those in conglomerates more generally. The lower levels of ownership concentration and the greater distance between parent and subsidiary in our sample of firms will be associated with a more efficiently operating capital market than in domestically wholly owned firms.

\section{Do parents reallocate capital more when their subsidiaries are in weak financial markets?}

We explore whether the quality of the institutional environment of the country in which the subsidiary is located relative to that of the parent influences the 'internal liquidity' and 'competition for funds' effects. There is evidence suggesting that foreign affiliates often substitute internal borrowing for external borrowing when operating in environments with poorly developed financial markets (Desai, Foley, and Hines, 2004). Table X indicates that in our sample, over 50\% pairs of firm are 'high-high', i.e. both subsidiaries and their parents are listed in a country with a high level of financial development. In $40 \%$ of the sample, subsidiaries but not their parents are located in countries with low financial development. 
Table X. Location of parents and subsidiaries by level of financial development

This table describes the distribution of subsidiaries across categories which describe both their and their parent's home country financial development, where "High Financial Development" indicates countries with above median ratios of Private Credit to GDP as measured by the World Bank. Data is from 4,200 parent-subsidiary pairs.

\begin{tabular}{lcc}
\hline & $\begin{array}{c}\text { Parent in High Financial } \\
\text { Development Country } \\
\% \text { Parent-subsidiary pairs: }\end{array}$ & $\begin{array}{c}\text { Parent in Low Financial } \\
\text { Development Country }\end{array}$ \\
\cline { 2 - 3 } $\begin{array}{l}\text { Subsidiary in High Financial } \\
\text { Development Country }\end{array}$ & $53.70 \%$ & $1.03 \%$ \\
$\begin{array}{l}\text { Subsidiary in Low Financial } \\
\text { Development Country }\end{array}$ & $40.50 \%$ & $5.64 \%$ \\
& & \\
\end{tabular}

Do subsidiaries in countries with relatively poor financial institutions benefit more from the availability of an internal capital market than those in countries with institutional quality closer to that of the parent, i.e. do we observe more reallocation? Or are they more vulnerable to influence costs? If the former, we predict a stronger effect of parent $Q$ on subsidiary investment when interacted with a measure of weakness of the financial institutions in the subsidiary's country. If information benefits outweigh excessive control and influence costs, we would predict enhanced Tobin's $Q$ effects in subsidiaries operating in countries with weaker domestic financial markets.

We test whether the sensitivity of investment to parent $Q$ in subsidiaries is responsive to the level of financial development broadly defined by the ratio of credit to the private sector to GDP. In Column 3 of Table IX, we look at foreign-owned firms and at whether the relative level of financial development between the country in which the subsidiary is located and that of its parent affects the role of the parent's $Q$ in the subsidiary's investment. Column 3 records that as the gap between the level of financial development in the subsidiary country and the owner country narrows (i.e. an increase in the index) the negative effect of parent $Q$ intensifies and efficient allocation within the MNE is enhanced. There is a 
smaller effect of parent $Q$ on investment in subsidiaries operating in weak financial markets. ${ }^{19}$ This is consistent with the hypothesis that influence effects are more likely to prevail when the subsidiary is in a weaker financial environment.

\section{Conclusions}

This paper investigates how the presence of a parent affects the investment behaviour of subsidiary firms. The study is relevant to several different but related literatures on internal capital markets, foreign direct investment and the macroeconomic experience of countries in financial crisis.

The approach we have taken is to examine the influence of foreign ownership in two stages. First in the context of internal versus external capital markets, we present evidence supporting the existence of internal capital markets that reallocate resources to members of multinational networks with superior investment opportunities. Second, we explore how various characteristics of the relationship between the subsidiary firm and its parent affect the efficiency of this reallocation. A new data set is employed that allows the investment opportunities of the subsidiary firm to be observed independently of those of the parent.

The results reported in this paper point to the efficient allocation of resources across subsidiaries in multinationals. The beneficial effects of foreign ownership are particularly in evidence when the ownership stake of the foreign parent is relatively modest and when the parent is distant from the subsidiary. The possible loss of information associated with smaller ownership stakes and greater distance appears to be outweighed by the potential influence drawbacks that arise from large ownership stakes and close proximity of a parent. The lower levels of parental ownership and greater distance between parents and listed subsidiaries of multinationals may explain the more positive evidence on the operation of internal capital markets that we find in multinationals than has been previously reported in divisions of domestic conglomerates.

\footnotetext{
${ }^{19}$ We note that allowing for heterogeneity of this kind brings out the significant positive effect of parent cash flow on subsidiary investment - a phenomenon we saw earlier when distance and ownership concentration were introduced.
} 
We also find that efficient allocation within MNEs is more in evidence as the gap between the level of financial development in subsidiary and owner country diminishes. This may reflect lower influence costs over subsidiaries that operate in better developed financial environments and,a capital allocation process that comes closer to an arms-length 'market' relation

Returning to the initial puzzle presented by investment behaviour in the Asian crisis, this paper suggests that the larger decline in foreign than domestic owned firm investment during the East Asian crisis is a consequence of the more extensive investment opportunities available to foreign-owned firms. Distant parents with small ownership stakes may have been particularly well placed to make objective commercial assessments without being subject to the same degree of local influence as domestic firms and those in close proximity to their subsidiaries. 


\section{References}

Abel, Andrew B and Janice C Eberly, 1996, HOptimal Investment with Costly ReversibilityH, HReview of Economic StudiesH 63(4), 581-93.

Berger, Philip G. and Eli Ofek, 1996, Bustup Takeovers of Value-Destroying Diversified Firms, Journal of Finance, 51(4), 1175-1200.

Bhagat, Sanjai, Andrei Shleifer and Robert W. Vishny, 1990, Hostile Takeovers in the 1980s: The Return to Corporate Specialization, Brookings Papers on Economic Activity. Microeconomics, 1-84.

Bond, Stephen and Jason Cummins, 2001, Noisy share prices and the $Q$ model of investment, IFS Working Papers, W01/22, Institute for Fiscal Studies.

Braun, Matias and Borja Larrain, 2005, Finance and the Business Cycle: International, Inter-Industry Evidence, Journal of Finance 60(3), 1097-1128

Brusco, Sandro and Fausto Panunzi, 2005. Reallocation of corporate resources and managerial incentives in internal capital markets, European Economic Review 49(3), 659-681,

Buch, Claudia M., 2005, Distance and International Banking, Review of International Economics 13(4), 787-804.

Burkhart, Michael, Dennis Gromb and Fausto Panunzi,1997, Large shareholders, monitoring and the value of the firm, Quarterly Journal of Economics 112, 693-728.

Chevalier, Judith, 2004, What Do We Know About Cross-subsidization? Evidence from Merging Firms, Advances in Economic Analysis \& Policy 4(1) Article 3.

http://www.bepress.com/bejeap/advances/vol4/iss1/art3

Çolak, Gönül and Toni M. Whited, 2005, Spin-offs, divestitures, and conglomerate investment, University of Wisconsin working paper.

Cooper, Russell and Joao Ejarque, 2001, Exhuming $Q$ : Market power versus capital market imperfections, NBER working paper,. 8182.

Cummins, Jason G., Kevin A. Hassett and Glenn R. Hubbard, 1996, Tax reforms and investment: A crosscountry comparison, Journal of Public Economics 62(1-2), 237-273. 
Desai, Mihir A., C. Fritz Foley and James R. Hines Jr., 2004, A Multinational Perspective on Capital Structure Choice and Internal Capital Markets, Journal of Finance 59, 2451- 2488.

Devereux, Michael P. and Fabio Schiantarelli, 1989, HInvestment, Financial Factors and Cash Flow: Evidence From UK Panel DataH, HNBER Working PapersH 3116, National Bureau of Economic Research.

Erickson, Timothy and Toni M Whited, 2000, Measurement error and the relationship between investment and q, Journal of Political Economy 108, 1027-1057.

Fazzari, Steven M., R. Glenn Hubbard \& Bruce C. Petersen, 1988, Investment-Cash Flow Sensitivities are Useful: A Comment on Kaplan and Zingales, Quarterly Journal of Economics 115, 695-705.

Ferris, Stephen P., Kenneth A. Kim and Pattanaporn Kitsabunnarat, 2003, The costs (and benefits?) of diversified business groups: The case of Korean chaebols, HJournal of Banking and FinanceH 27(2), 251273.

Gertner, Robert H., Eric Powers and David S. Scharfstein, 2002, Learning about internal capital markets from corporate spinoffs Journal of Finance 57, 2479-2506.

Gertner, Robert H., David S. Scharfstein and Jeremy C. Stein, 1994, Internal versus external capital markets, Quarterly Journal of Economics 109, 1211-1230.

Gomes, Joao F., 2001, Financing Investment, American Economic Review 91, 1263-1286.

Graham, John R., Michael L. Lemmon and Jack G. Wolf, 2002, Does corporate diversification destroy value, Journal of Finance 57, 695-720.

Grinblatt, Mark and Matti Keloharju, 2001, How Distance, Language and Culture Influence Stockholdings and Trades, Journal of Finance 56, 1053-1073.

Guiso Luigi, Paola Sapienza and Luigi Zingales, 2004, Does Local Financial Development Matter? Quarterly Journal of Economics 119(3), 929-969.

Hoshi, Takeo, Anil Kashyap and David S. Scharfstein, 1991, Corporate structure, liquidity, and investment: evidence from Japanese industrial groups, Quarterly Journal of Economics 106, 33-60.

Inderst, Roman and Holger M. Müller, 2003, Internal vs. External Financing: An Optimal Contracting Approach, Journal of Finance, 58 (3), 1033-1062. 
Kaplan, Steven N. and Luigi Zingales, 1997, Do investment-cash flow sensitivities provide useful measures of financing constraints, Quarterly Journal of Economics 112, 169-215.

Lamont, Owen, 1997, Cash flow and investment: evidence from internal capital markets, Journal of Finance 52, 83-109.

Li, David D. and Shan Li, 1996, A theory of corporate scope and financial structure, Journal of Finance $51,691-709$.

Lipsey, Robert E., 2001, Foreign Investors in Three Financial Crises, NBER Working Paper No. 8084.

Maksimovic, Vojislav and Gordon M. Phillips, 2002, Do conglomerate firms allocate resources inefficiently across industries? Theory and evidence, Journal of Finance 57, 721-767.

Meyer, Margaret, Paul Milgrom and John Roberts, 1992, Organizational prospects, influence costs, and ownership changes, Journal of Economics and Management Strategy 1, 9-35.

Mian, Atif, 2005, Distance constraints: the limits of foreign lending in poor economies, Mimeo, Graduate School of Business, University of Chicago.

Milgrom, Paul, 1988, Employment contracts, influence activities, and efficient organization design, Journal of Political Economy 96, 42-60.

Milgrom, Paul and John Roberts, 1988, An economic approach to influence activities in organizations, American Journal of Sociology 94, 154-179.

Morck Randall and Masao Nakamura, 1999, Banks and Corporate Control in Japan, Journal of Finance 54(1), 319-339.

Portes Richard and Helene Rey, 2001, The Determinants of Cross-Border Equity Flows: The Geography of Information, International Finance, Economics Working Paper Archive

Prowse, Stephen D., 1992, The Structure of Corporate Ownership in Japan, Journal of Finance 47(3), 1121-40.

Radelet, Steven and Jeffrey D. Sachs, 1998, The East Asian Financial Crisis: Diagnosis, Remedies, Prospects, Brookings Papers on Economic Activity 1, 1-90.

Rajan, Raghuran, Henri Servaes and Luigi Zingales, 2000, The cost of diversity: the diversification discount and inefficient investment, Journal of Finance 55, 35-80. 
Scharfstein, David S., 1998, The dark side of internal capital markets II: evidence from diversified conglomerates, NBER Working Paper 6352 (NBER, Cambridge, MA.

Scharfstein, David S. and Jeremy C. Stein, 2000, The dark side of internal capital markets: divisional rentseeking and inefficient investment, Journal of Finance 55, 2537-2564.

Shin, Hyun-Han and René M. Stulz, 1998, Are Internal Capital Markets Efficient?, Quarterly Journal of Economics 113(2), 531-552.

Stein, Jeremy C., 2003), Agency, Information and Corporate Investment, in George Constantinides, Milt Harris and Rene Stulz (eds.) Handbook of the Economics of Finance (Elsevier), 111-165.

Stock, James H. and Motohiro Yogo, 2003, Testing for Weak Instruments in Linear IV Regression, manuscript, Harvard University.

Wei Shang-Jin and Yi Wu, 2001, Negative Alchemy? Corruption, Composition of Capital Flows, and Currency Crises, NBER Working Papers 8187, National Bureau of Economic Research

Weinstein David E. and Yishay Yafeh, 1998, On the Costs of a Bank-Centered Financial System: Evidence from the Changing Main Bank Relations in Japan, HJournal of FinanceH 53(2), 635-672.

Whited, Toni M., 2001, Is it inefficient investment that causes the diversification discount?, Journal of Finance 56, 1667-1691. 


\title{
Appendix: Construction of the data-set
}

\author{
A. Primary source \\ We begin with the population of firms listed on the world's stock exchanges provided by the OSIRIS \\ database published by Bureau van Dijk Electronic Publishing which gathers its information from several \\ sources including World'Vest Base, Fitch, Thomson Financial, Reuters, and Moody's. For 2005, there are \\ 28,915 firms listed on the world's stock exchanges. Table 1 presents the distribution of these firms by \\ country.
}

\section{B. Identifying stand-alone, owned and owner firms in the data-set.}

The OSIRIS data records a firm as having a parent if another entity has financial and legal responsibility for it, i.e., it holds more than 50 per cent and less than 100 per cent of the subsidiary's equity.

The OSIRIS data only reports ownership at one point in time 2005, but we have older ownership data from Dun and Bradstreet which enables us to identify ownership in 1994. After matching these data we exclude firms from the sample if the location of their owner is different in these two datasets.

We discard subsidiary firms from the sample if they experienced a change in ownership over the period, or if their ownership information is unavailable, or if key financial information (matched to and collected from Datastream) is missing over the period. This leaves us with 4,886 subsidiaries which have been continuously owned and controlled by 1,028 distinct global ultimate firms over the period.

\section{Sources and definitions of variables}

The OSIRIS data-base reports a unique identification number for each parent firm that enables us to match firms with financial data on their parents. This was merged with the market and financial data from Datastream. 
The parent's data is given in consolidated form, so we take out the effect of the subsidiary to extract the parent's pure data. ${ }^{20}$

Capital expenditure: funds used to acquire fixed assets including expenditures on plant and equipment, structures and property but excluding any expenditures associated with mergers or acquisitions. To account for differences in size and for inflation over time and to avoid heteroscedasticity we divide investment by total assets at the beginning of the period. Datastream item 08416 Asset Utilization Ratio measured as the annual item Capital Expenditures / (Total Assets - Customer Liabilities on Acceptances).

Average $Q$ : the firm's market-to-book ratio at the end of the prior fiscal year. To calculate parent's $Q$, we took the effect of subsidiary variables out of consolidated data in order to get parent's data, i.e. Total $Q=$ asset-weighted sum of parent and subsidiary $Q$; from which we calculate unconsolidated $Q . Q$ is the share price divided by the book value per share (Datastream PTBV).

Liquidity. Cash flow divided by total assets at the start of the year. Datastream item 04860 (Net cash flow from operating activities) divided by total assets. $Q$ is the share price divided by the book value per share (Datastream PTBV).

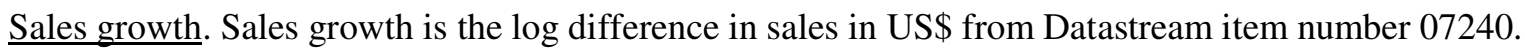

Distance to owner is the great circle distance between capital cities of the two countries measured as a percentage of half the earth's circumference (i.e. max is 100).

\footnotetext{
${ }^{20}$ For example we use the employment in the subsidiary $E_{i}$ and the total consolidated employment, $E_{T}$ to determine the firm's $Q_{j}$ which we call parent's $Q$, but really refers to the $Q$ of the entire entity except the subsidiary. The firm's consolidated $Q$ is $Q_{T}=\left(\left(Q_{i}{ }^{*} E_{i}+Q_{j}{ }^{*} E_{j}\right) / E_{T}\right)$. So parent's $Q$ is $Q_{j}=\left(Q_{T} * E_{T} Q_{i}{ }^{*} E_{i}\right) / E_{j}$.
} 
Employees is Datastream item WC07011.

Ratio of credit to the private sector to GDP and size of the stock market to GDP.

Recession year dummy. Quarterly GDP data from the IMF's International Financial Statistics (IFS). The recession dummy variable indicating whether a country is experiencing a recession in a particular year is constructed following Braun and Larrain (2005). For each country 'troughs' are identified as years when the current log of real local currency GDP (from World Bank, 2005) deviates by more than one standard deviation from its trend level (computed using the Hodrick-Prescott filter with a smoothing parameter of 100). A local peak is then defined as the most recent year for which cyclical GDP (the difference between actual and trend values) is higher than the previous and posterior years. The recession variable is one for the years between the peak and trough (excluding the peak year), and zero for other years. 